\title{
Changes in range-wide distribution of plains topminnow Fundulus sciadicus
}

\author{
Chelsey A. Pasbrig ${ }^{1}$, Keith D. Koupal ${ }^{2}$, Steve Schainost ${ }^{3}$, W. Wyatt Hoback ${ }^{1, *}$ \\ ${ }^{1}$ University of Nebraska at Kearney, Department of Biology, Kearney, Nebraska 68849, USA \\ ${ }^{2}$ Nebraska Game and Parks Commission, District VI Office, Kearney, Nebraska 68847, USA \\ ${ }^{3}$ Nebraska Game and Parks Commission, Northwest Regional Office, Alliance, Nebraska 69301, USA
}

\begin{abstract}
Globally, riverine fishes are affected by degradation of habitat, stream alterations, lost stream connectivity and introduction of non-native species. The plains topminnow Fundulus sciadicus, a small stream-dwelling fish, currently does not have a federal conservation status in the USA $;$ however, anecdotal reports have suggested its decline for the last $20 \mathrm{yr}$. Our goals were to evaluate the validity of its reported decline and to determine the current range-wide status of this species. We identified 927 historical sites (1889-1999) of occurrence and compiled recent records or re-visited 667 sites (2000-2010). We found plains topminnow at $189(28.0 \%)$ of these sites. Although Nebraska represented the center of distribution and included $66.7 \%$ of all historical sites, plains topminnow were only found at $34.4 \%$ of historical sites, with the largest declines observed in the Platte and Republican River drainages. Current sampling efforts in Colorado, Missouri, Oklahoma, South Dakota and Wyoming found similar declines. In Iowa and Kansas, plains topminnow was not found, whereas potential increases in distribution were observed in a single drainage in Minnesota and Wyoming. In addition to our sampling efforts, we repeatedly sampled 40 sites within Nebraska to determine detection probability. Detection probabilities for plains topminnow were consistent at $0.76 \pm 0.05$ (mean $\pm \mathrm{SE}$ ) among sites that were sampled with a single visit. Further research is needed on the species and the potential threats to its occupation of sites, as no singular cause for decline seems plausible. Observed threats include degradation and loss of habitat and shifts in species assemblages towards generalist non-native species.
\end{abstract}

KEY WORDS: Fundulus sciadicus $\cdot$ Plains topminnow $\cdot$ Fundulidae $\cdot$ Endemic $\cdot$ Decline $\cdot$ Threat

\section{INTRODUCTION}

Globally, the range and abundance of many endemic riverine fishes are declining (Ricciardi \& Rasmussen 1999, Williams et al. 2008). Anthropogenic disturbances to physical habitat, including degradation of habitat, stream alterations, and loss of stream connectivity, have led to the reduction and loss of several species (Richter et al. 1997, Zabel \& Williams 2002, Wang et al. 2008, Volcan et al. 2011) and have also altered species assemblages (Cumming 2004, Fischer \& Paukert 2008, Jowett et al. 2009). Other factors that have led to the loss or decline of freshwater species include reductions of water quality from pollution (Austin 1998, Bonner \& Wilde 2002) and the introduction of non-native species (Lynch 1988, Crowl et al. 1992, Rahel 2002).

Management and conservation of riverine species with patchy distributions are especially complicated because of the challenges in detecting long-term changes (Fischer \& Paukert 2008). Often, historical documentation of range and density is lacking and baseline data from periods before human alterations are unavailable (Matthews 1988, Ulltang 1998). Ad- 
ditionally, lotic systems are geographically expansive and can be influenced by multiple alterations and disturbances at the same time, which makes determining the primary causes for species decline and loss difficult (McCartney 2002).

The plains topminnow Fundulus sciadicus is endemic to the central United States (Fig. 1) with 2 disjunct populations (Lee et al. 1980). The largest distribution is centered in Nebraska and extends to northeastern Colorado, southwestern Wyoming, southern South Dakota, southwestern Minnesota and Iowa (Baxter \& Stone 1995, Weitzel 2002, Rahel \& Thel 2004). The second population is centered in Missouri and extends from Kansas south to Oklahoma (Pflieger 1997) (Fig. 2). The plains topminnow

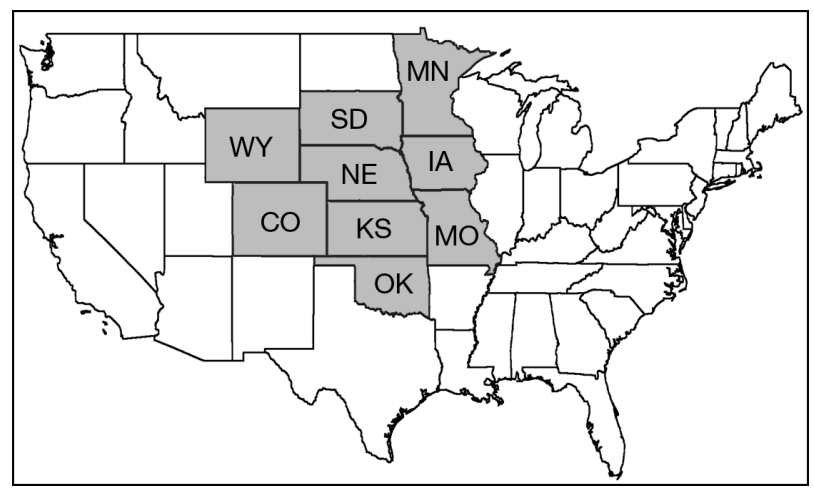

Fig. 1. The historical distribution of plains topminnow Fundulus sciadicus encompasses 9 central states: Colorado (CO), Wyoming (WY), South Dakota (SD), Nebraska (NE), Kansas (KS), Oklahoma (OK), Minnesota (MN), Iowa (IA) and Missouri (MO)

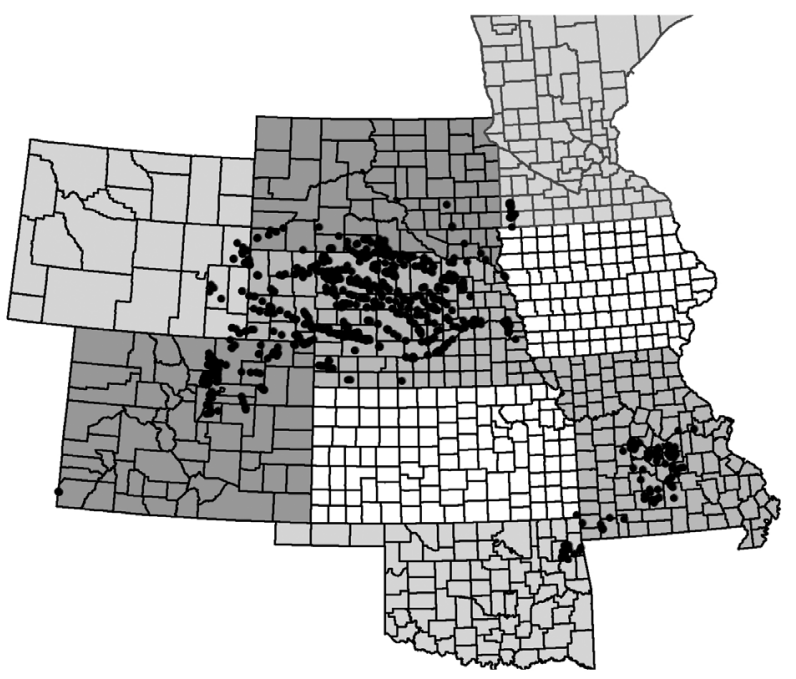

Fig. 2. Historical locations $(n=927)$ of plains topminnow occurrence across their 9-state geographic range (see Fig. 1).

Historical data were collected between 1889 and 1999 is currently ranked as globally secure according to the Natural Heritage database (NatureServe 2011). However, all states in the native range, except Oklahoma, recognize some level of concern for plains topminnow. In Iowa and Kansas, plains topminnow is presumed extirpated (Harlan et al. 1987, Haslouer et al. 2005). South Dakota (Bailey \& Allum 1962, Brinkman 1994) lists plains topminnow as threatened whereas in Minnesota, Missouri, Colorado (Everhart \& Seaman 1971), Wyoming (Weitzel 2002) and Nebraska, plains topminnow is listed as a species of special concern (NatureServe 2011). Recent (2004-2005) sampling in Nebraska at 130 sites where plains topminnow historically occurred found that $29.2 \%$ of sites were occupied by the species (Haas 2005). At a broader scale, recent surveys to detect plains topminnow distribution as compared to available historical data across its range had not been attempted. The goals of this study were to compare current and historical distribution records, evaluate additional sites for plains topminnow presence, determine sampling effectiveness via detection probability and document potential threats. The objectives of this project were to: (1) conduct surveys of all accessible sites with historical records of plains topminnow to determine whether they were still present, (2) conduct surveys in additional potentially suitable sites to determine scope of distribution, (3) quantify detection probabilities of plains topminnow with an established sampling protocol, and (4) use our results to describe current plains topminnow distribution while considering factors that have potentially influenced their distribution.

\section{MATERIALS AND METHODS}

\section{Study area}

The historical distribution of plains topminnow and extent of this study includes a 9 state range (Fig. 1). Historical distribution records were obtained from either the Natural Heritage Program Database or state natural resource agency databases. A current record was based on an a priori definition using criteria of the United States Fish and Wildlife Service (USFWS) and was defined as all records sampled within the $10 \mathrm{yr}$ previous to the termination of data collection for this study (2000-2010). Historical records were defined as all records collected prior to 1 January 2000 (1889-1999). Historical records may fall outside of the native distribution because plains topminnow has been presumed to be introduced into 
some drainages with stockings. However, for the purpose of determining current presence at historical sites, we used all documented occurrences of the species. Historical sites found to have a dry channel were currently counted as absent for plains topminnow. For Nebraska, dry sites observed in the past $10 \mathrm{yr}$ were revisited in later years and sampled when water was present.

\section{Field collection}

Within a watershed, plains topminnow display a preference for slow-moving, low-gradient streams and peripheral habitats (e.g. vegetated channel edges and backwaters) of larger streams, and are rarely found in the main channel (Cross \& Collins 1995, Pflieger 1997, Rahel \& Thel 2004). Current sampling efforts were provided by several biologists from surrounding state and federal agencies working throughout the study area. Of the 667 historical sites currently sampled, approximately two-thirds were sampled using the sampling protocol defined by this study (Iowa, Kansas, Missouri, Nebraska and South Dakota) whereas the remaining sites (Colorado, Iowa, Minnesota, Missouri, Nebraska, Oklahoma and Wyoming) were sampled following the appropriate state natural resource agency's wadeable stream protocol (Table 1).

This study located a historical site using a global positioning system and then sampled a minimum length of $150 \mathrm{~m}$ and a maximum length of $300 \mathrm{~m}$. The sampling protocol followed by this study (hereafter referred to as 'study protocol') included multiple passes using a series of sampling gears appropriate to the site. Because this study sought to establish the presence or absence of plains topminnow at a site, when topminnow were collected, no additional sampling passes with other gears were conducted. The initial and primary fish collection method used 2 passes with dip netting (bar $3.2 \mathrm{~mm}$ mesh). If unsuccessful, 2 passes with seines $(6.4 \times 1.2 \mathrm{~m}, 6.4 \mathrm{~mm}$ mesh) and finally one pass of electrofishing with a backpack pulsed DC electrofisher was used. If no plains topminnow were captured using the 3 sample methods at a site, then plains topminnow were deemed to be absent.

At some sites, not all sampling gear types were suitable and judgment was used in instances where certain gears would work better. For example, seines were not used at sites where the backwaters were obstructed by submerged woody debris; instead, these sites were sampled with dip netting and electrofishing. All captured fish were identified, counted and released in the field. Voucher specimens were taken at each sampling location and preserved in $10 \%$ formalin to be stored at the Nebraska Game and Parks Commission (NGPC) Northwest District Office in Alliance, Nebraska.

Additional sites on streams with historical presence $(n=1109)$ were also sampled in an effort to find new sites occupied by plains topminnow. Potential new plains topminnow locations were sampled as a collective effort by several biologists and state natural resource agencies (Colorado, Iowa, Minnesota, Missouri, Nebraska, Oklahoma and Wyoming) and by the present study (Iowa, Kansas, Nebraska, Oklahoma and South Dakota). Of the additional sites sam-

Table 1. Historical and current sampling efforts of plains topminnow distribution, including records from historical and new sampling locations across the geographic distribution

\begin{tabular}{|c|c|c|c|c|c|c|c|c|}
\hline \multirow[t]{2}{*}{ State } & \multirow{2}{*}{ No. sites } & \multirow{2}{*}{$\begin{array}{c}\text { Hist } \\
\text { No. sites } \\
\text { visited }\end{array}$} & \multirow{2}{*}{$\begin{array}{l}\text { Nal } \\
\text { No. sites } \\
\text { occupied }\end{array}$} & \multirow[b]{2}{*}{$\begin{array}{c}\text { Study } \\
\text { protocol }\end{array}$} & \multirow{2}{*}{ No. sites } & \multirow{2}{*}{$\begin{array}{l}\text { Potential } \\
\text { No. sites } \\
\text { occupied }\end{array}$} & \multirow[b]{2}{*}{$\begin{array}{l}\text { Study } \\
\text { protocol }\end{array}$} & \multirow{2}{*}{$\begin{array}{c}\text { Total sites } \\
\text { occupied }\end{array}$} \\
\hline & & & & & & & & \\
\hline Colorado & 131 & 131 & 13 & 0 & $12^{\mathrm{b}}$ & 12 & 0 & 25 \\
\hline Iowa & $5^{\mathrm{a}}$ & 3 & 0 & 1 & 65 & 0 & 21 & 0 \\
\hline Kansas & 1 & 1 & 0 & 1 & 4 & 0 & 4 & 0 \\
\hline Minnesota & 14 & 7 & 7 & 0 & 411 & 33 & 0 & 40 \\
\hline Missouri & 74 & $38^{\mathrm{b}}$ & 9 & 36 & $28^{\mathrm{b}}$ & 28 & 0 & 37 \\
\hline Nebraska & 618 & 427 & 147 & 374 & 308 & 44 & 104 & 191 \\
\hline Oklahoma & 18 & 18 & 0 & 0 & $7^{b}$ & 2 & 5 & 2 \\
\hline South Dakota & 41 & 32 & 6 & 32 & 7 & 5 & 7 & 11 \\
\hline Wyoming & 25 & 10 & 7 & 0 & 267 & 78 & 0 & 85 \\
\hline Total & 927 & 667 & 189 & 444 & 1109 & 202 & 141 & 391 \\
\hline
\end{tabular}


pled, $86.5 \%$ were provided by state natural resource agencies as a part of stream surveys by each state (Table 1). Additional sites were sampled within streams where historical presence was documented, or in drainages where records were considered introductions outside the native range. Sites sampled by efforts outside of this project were defined by the boundaries and protocols established by the biologist or agency that generated the records.

\section{Sampling locations}

\section{Colorado}

Historical data were obtained from the Colorado Division of Wildlife (CDW) database (CDW unpubl. data). The most extensive historical surveys of Colorado were conducted in the early 1990s with plains topminnow collected at 131 stream sites in northeastern Colorado (Fig. 2, Table 1). These occurrences were primarily located within tributaries to the South Platte and Cache La Poudre Rivers.

During 2000-2009, 131 historical sites were resampled following the CDW Warm-water Stream Survey-Stepwise Onsite Protocol (Crockett 2008). Twelve additional sites were included in the current sampling efforts. The CDW database did not indicate how many new locations were sampled; rather, it only indicated the sites that had plains topminnow.

Iowa

Historical surveys were obtained from the Iowa Department of Natural Resources (IDNR) database (IDNR unpubl. data). Historically 4 published records for plains topminnow exist in Iowa (Harlan \& Speaker 1956); however, only one of these records can be considered valid (IDNR unpubl. data). All 4 records were from northwest Iowa River basins (Rock, Floyd and Little Sioux). Two records (reported as plains killifish Fundulus zebrinus) were from the survey of Seth Meek (Meek 1894); single records were from Iowa fisheries biologists W. Aitken and E. Speaker. Work by Hubbs (1926) suggested that Meek's record for plains topminnow from East Okoboji Lake in the Little Sioux River basin was in error. Meek's (1894) record for the Floyd River at Sioux City may also be in error, as no topminnows were reported in his Floyd River collection at Sioux City (IDNR unpubl. data). Studies of fish in Iowa's Okoboji lakes by Larrabee (1926) and Johnson (1942) suggest that Speaker's record from the Little Sioux River in Dickinson County was similarly in error (IDNR unpubl. data). Aitken's 1941 record from a tributary of the Rock River in Lyon County was the only Iowa record for plains topminnow that has been verified (verification by Carl Hubbs, University of Michigan Museum of Zoology). Review of Meek's (1894) collections in northwest Iowa suggests that his record for Zygonectes sciadicus from the Floyd River in Plymouth County represents an additional valid Iowa record for plains topminnow (IDNR unpubl. data).

In June 2009, 3 historical sites were sampled by this study along with IDNR personnel following the study protocol. Sixty-five additional sites were also included in the current sampling efforts (Fig. 2, Table 1). Of these, 21 were sampled in the present study, with the remaining sites sampled between 2000 and 2009 by IDNR during Topeka shiner Notropis topeka surveys (IDNR unpubl. data).

Kansas

Historical surveys were obtained from the Kansas Department of Wildlife and Parks (KDWP) database (KDWP unpubl. data). A single record for plains topminnow was reported in 1963, in southeastern Kansas, Cherokee County (Fig. 2, Table 1). This occurrence was located in Shoal Creek, a tributary to the Spring River. In addition, Cross \& Collins (1995) suggested the potential for plains topminnow within Cheyenne County, which contains tributaries to the Republican River; however, no voucher specimens existed. In July 2009, the single historical site was sampled following study protocol. Four additional sites on the Spring and Republican Rivers were sampled using the protocols of this study (Fig. 2, Table 1).

\section{Minnesota}

Historical surveys were obtained from the Minnesota Department of Natural Resources (MDNR) database (MDNR unpubl. data). Plains topminnow were first recorded in 1973 (Anderson et al. 1977). The most extensive historical surveys of Minnesota were conducted by Schmidt in 1988 and 1989 (MDNR unpubl. data). Historical surveys found plains topminnow at 14 stream sites in southwestern Minnesota (Fig. 2, Table 1). These occurrences were all located within tributaries to the Rock River. 
In 2000 to 2009,7 of the 14 historical sites were sampled following the University of Minnesota (UM) Topeka shiner monitoring program stream sampling protocol (Ceas \& Larson 2009). An additional 411 sites were also sampled by UM staff (Fig. 2, Table 1).

\section{Missouri}

Historical survey data were obtained from the Missouri Department of Conservation (MDC) database (MDC unpubl. data). Historical surveys of Missouri were described by Pflieger (1997), with the first plains topminnow record from 1931. Plains topminnow occurred along the northern and western edges of the Ozarks from Lost and Shoal Creeks in southwestern Missouri to tributaries of the Missouri River. The populations in southwestern Missouri are isolated from the majority of plains topminnow population distributions in central Missouri. Historical surveys found plains topminnow at 74 stream sites in Missouri (Fig. 2, Table 1). These occurrences were located within tributaries to the Gasconade, Missouri, Osage and Spring Rivers.

From 2000 to 2007, historical sites were sampled by the MDC following the MDC Resource and Assessment Monitoring sampling protocol (Fischer \& Combes 2003). The database provided by MDC did not indicate the complete sampling efforts or the number of historical sites or new sampling locations that were recently sampled, and only indicated the sites sampled where plains topminnow were found. In October 2009, 36 historical sites were sampled following the study protocol. Restrictions of the approved sampling permit limited access to 8 of the 19 counties containing historical records for plains topminnow. Based on the MDC database's complete sampling efforts being unknown and the restrictions on the approved sampling permit, the present study can report that 38 of the 74 historical sites have been currently sampled in Missouri. Twenty-eight additional sites were sampled by the MDC (Fig. 2, Table 1).

\section{Nebraska}

Historical surveys were obtained from the NGPC database (NGPC unpubl. data) to determine historical plains topminnow distributions in Nebraska. The most extensive historical surveys of Nebraska streams were conducted by Johnson between 1939 and 1940 (Johnson 1942) and Lynch and Kaufmann between 1989 and 1995 (NGPC unpubl. data). His- torical surveys collected plains topminnow at 618 stream sites throughout Nebraska, with the majority located within the Sandhills region of north-central Nebraska and within the Platte River drainage (Fig. 2 , Table 1). Historical occurrences were documented in the drainages of the Elkhorn, Loup, Niobrara, Platte and Republican Rivers. Records in the Republican River drainage were presumed to be introduced (Rahel \& Thel 2004).

From 2000 to 2010, 427 of the 618 historical sites were visited. An additional 308 sites were included in the current sampling efforts (Fig. 2, Table 1). Current sampling efforts were provided by Haas (2005), the Nebraska Department of Environmental Quality (DEQ) (Bazata 2005), the NGPC, and the present study. Sampling followed the study protocol, with the exception of the historical sites sampled by Haas (2005) and DEQ (Bazata 2005).

\section{Oklahoma}

Historical surveys were obtained from Oklahoma museum records (Heth 2005). The most extensive historical surveys of Oklahoma were conducted in 1927 by Hubbs \& Ortenburger (1929), with plains topminnow collected at 18 sites in northeastern Oklahoma (Fig. 2, Table 1) from tributaries of the Neosho River.

From 2000 to 2008, all historical sites were sampled by Missouri Southern State University (MSSU) and USFWS staff following the MSSU sampling protocol (Heth 2005). Seven additional sites were included in the current sampling efforts (Fig. 2, Table 1). Of these, 5 were sampled by this study with the remaining sites sampled from 2000 to 2008 by MSSU (Heth 2005).

\section{South Dakota}

Historical surveys were obtained from the South Dakota Game and Fish (SDGF) database (SDGF unpubl. data). The most extensive historical surveys of South Dakota were conducted in 1993 and 1994. A total of 41 sites contained plains topminnow, all located in southern South Dakota (Fig. 2, Table 1). These occurrences were contained in the Cheyenne, Keya Paha, Little White, Big Sioux, Niobrara, Vermillion and James River drainages. During 2009, 32 of the 41 historical sites were sampled following the study protocol. Seven additional sites were also sampled (Fig. 2, Table 1). 


\section{Wyoming}

Historical surveys were obtained from the Wyoming Game and Fish Department (WGFD) database (Patton \& Hubert 1993, WGFD unpubl. data). The most extensive historical surveys of Wyoming were conducted by Simon (1946) and Baxter \& Simon (1970), with plains topminnow collected at 25 sites (Fig. 2, Table 1). These occurrences were located in tributaries to the Niobrara, North Platte, South Platte and Cheyenne Rivers in the southeastern portion of the state. Records in the Cheyenne River drainage were presumed to be introduced (Baxter \& Simon 1970). Between 2004 and 2009, 10 of the 25 historical sites were sampled following the WGFD Prairie Streams Conservation Project Protocol (Environmental Monitoring and Assessment Program 1991, Quist et al. 2004). An additional 267 sites were included in current sampling efforts by the WGFD.

\section{Detection probability}

To determine the detection probabilities associated with the study protocol, we selected 40 sites in Nebraska (Fig. 3) to sample repeatedly. These sites were referred to as intensive monitoring sites. Ten intensive sites included historical plains topminnow presence; however, plains topminnow had not been observed for the past 10 yr (0 individuals found in recent sampling). Ten intensive sites each had low ( $\leq 5$ individuals), moderate (6 to 29 individuals) and high ( $\geq 30$ individuals) abundance of

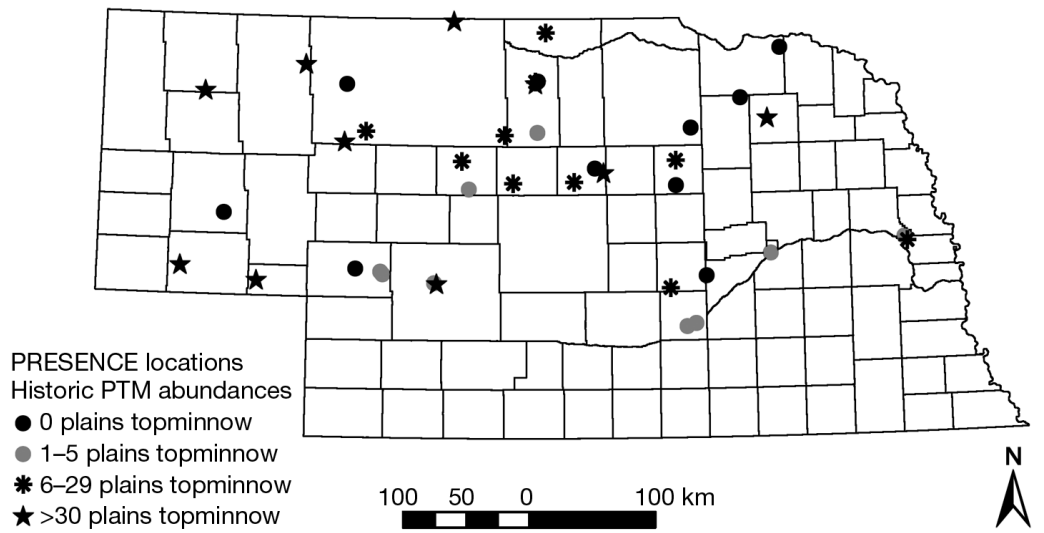

Fig. 3. Forty sites in Nebraska were selected for intense sampling and were subsequently repeatedly sampled 3 separate times to determine the sampling effectiveness via detection probability for plains topminnow (PTM). Sites were randomly selected for 4 different abundances of previously collected plains topminnow (high, $\geq 30$ individuals, $\mathrm{n}=10$; moderate, 6 to 29 individuals, $\mathrm{n}=10$; low, $\leq 5$ individuals, $\mathrm{n}=10$; or none, $\mathrm{n}=10$ ) plains topminnow, based on sampling in the last 10 yr (2000-2010). Each intensive monitoring site was sampled with the same amount of effort using all 3 sampling gears.

At intensive monitoring sites, the study protocol was employed on 3 occasions in July 2009. By conducting multiple visits to each intensive monitoring site, the detection probability for plains topminnow at a given location within a given sampling effort was estimated using the program PRESENCE version 2.3 and Stat Trek (PRESENCE) (MacKenzie et al. 2004, StatTrek 2009). Detection probabilities were determined for 1, 2 and 3 sampling visits as well as for each abundance category and are reported with the associated standard error.

\section{RESULTS}

\section{Historical and new locations}

Revisiting 667 of the 927 sites of historical occurrence yielded plains topminnow at 189 sites $(28.3 \%$; Fig. 4, Table 1). Of the additionally sampled sites, 202 of $1109(18.2 \%)$ surveyed contained plains topminnow (Fig. 5, Table 1).

\section{Colorado}

Plains topminnow were present at $9.9 \%$ of 131 historical collection sites (Fig. 4, Table 1). In addition, the species was collected at 12 previously unsampled sites (Fig. 5, Table 1). However, the CDW database did not include complete sampling efforts at new sampling locations; thus, the results do not include the number of sites surveyed from which plains topminnow were not collected. Presently, plains topminnow were found to primarily inhabit tributaries to the Cache La Poudre and South Platte Rivers. The abundance of plains topminnow was low ( $\leq 5$ individuals) at $52.0 \%$ of the 25 recent collection localities in Colorado (Table 2).

\section{Iowa}

Plains topminnow were not found at any of the 3 potential historical 


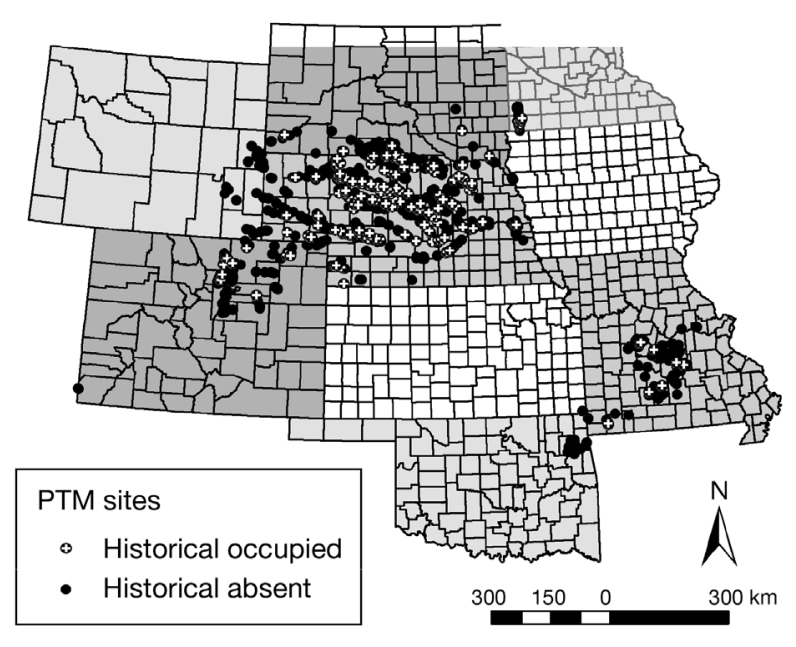

Fig. 4. Historical sites sampled between 2000 and 2010 (n = 667 ) that were found to currently support plains topminnow (PTM) populations $(\mathrm{n}=189)$ and historical sites where plains topminnow were not found $(\mathrm{n}=478)$. Information from the Missouri database did not include complete sampling efforts at historical sites

collection sites, including the one historical site that was confirmed with a voucher specimen (Fig. 4 , Table 1). In addition, the species was not collected at the 65 previously unsampled sites (Fig. 5, Table 1). In Iowa, the plains topminnow is presumed to be extirpated.

\section{Kansas}

Plains topminnow were not found at the single historical collection site in Kansas (Fig. 4, Table 1). In addition, the species was not collected at the 4 previously unsampled sites (Fig. 5, Table 1). In Kansas, the plains topminnow is presumed to be extirpated.

\section{Minnesota}

Plains topminnow were present at all of the 7 historical collection sites sampled (Fig. 4, Table 1). In addition, the species was collected at 33 of the 411 previously unsampled sites (Fig. 5, Table 1). Presently, plains topminnow is restricted to tributaries to the Rock River in southwestern Minnesota. The abundance of plains topminnow was low ( $\leq 5$ individuals) at $69.2 \%$ of 26 recent collection localities in Minnesota that reported abundance (Table 2).

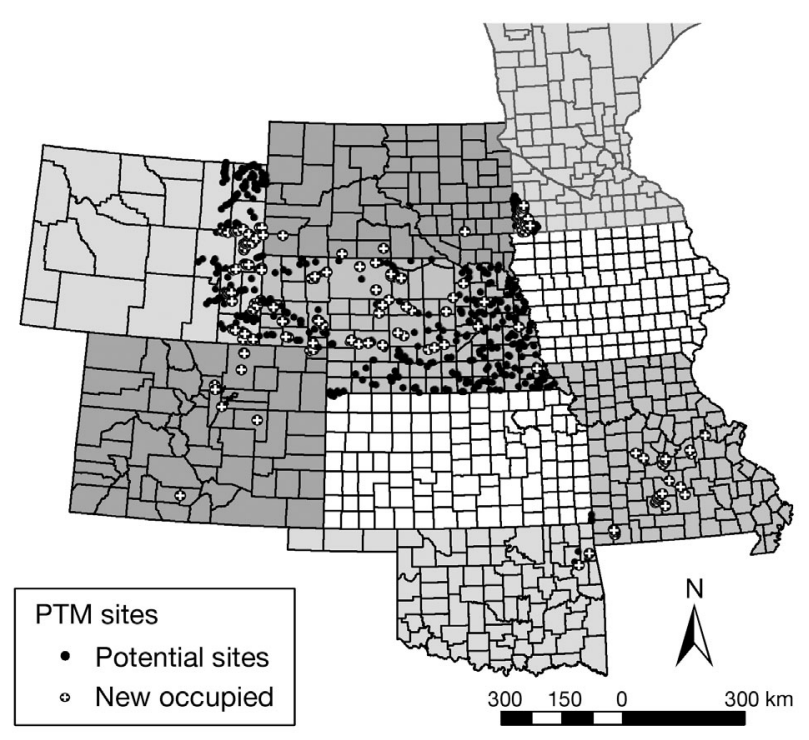

Fig. 5. New locations sampled $(n=1109)$ that were not included in the historical distribution of plains topminnow (PTM). Plains topminnow were found at 202 new sites ( $18.2 \%$ of the sites surveyed). Information from Missouri and Colorado databases did not include complete sampling efforts at new sampling locations

Table 2. Fundulus sciadicus. Relative abundances of plains topminnow at recorded current sampling locations. Abundances were recorded as high ( $\geq 30$ individuals), moderate (6 to 29 individuals) or low ( $\leq 5$ individuals). Abundance data should be cautiously interpreted because equal sampling effort was not conducted at all sites within or among states

\begin{tabular}{|c|c|c|c|c|c|}
\hline State & $\begin{array}{c}\text { Total } \\
\text { occupied }\end{array}$ & $\begin{array}{l}\text { Reported } \\
\text { abundance }\end{array}$ & $\overline{\text { High }}$ & $\begin{array}{c}\text { Abundance } \\
\text { Moderate }\end{array}$ & $\overline{\text { Low }}$ \\
\hline Colorado & 25 & 25 & 9 & 3 & 13 \\
\hline Iowa & 0 & 0 & - & - & - \\
\hline Kansas & 0 & 0 & - & - & - \\
\hline Minnesota & 40 & 26 & 3 & 5 & 18 \\
\hline Missouri & 37 & 7 & 0 & 2 & 5 \\
\hline Nebraska & 191 & 191 & 30 & 23 & 138 \\
\hline Oklahoma & 2 & 2 & 2 & 0 & 0 \\
\hline South Dakota & a 11 & 11 & 0 & 5 & 6 \\
\hline Wyoming & 85 & 61 & 22 & 14 & 25 \\
\hline Total & 391 & 323 & 66 & 52 & 205 \\
\hline
\end{tabular}

Missouri

Plains topminnow were present at $23.7 \%$ of the 38 historical collection sites sampled (Fig. 4, Table 1). In addition, the species was collected at 28 previously unsampled sites (Fig. 5, Table 1). However, the MDC database did not include complete sampling efforts at new sampling locations; thus, the results did not 
include the number of sites surveyed from which plains topminnow were not collected.

\section{Nebraska}

In Nebraska, 43 of the historical sites were dry during at least one visit. Plains topminnow were present at $34.4 \%$ of the 427 historical collection sites sampled (Fig. 4, Table 1). In addition, the species was collected at 44 of 308 previously unsampled sites (Fig. 5, Table 1). Plains topminnow were primarily found in tributaries to the Loup, Elkhorn and Dismal Rivers. In Nebraska, the largest declines in plains topminnow sites were observed within the Platte and Republican River drainages. Historically, the Platte River drainage held 215 historical plains topminnow locations, of which $20.0 \%$ currently support the species. The plains topminnow is suggested to be introduced in the Republican River (Rahel \& Thel 2004); however, this study identified 22 historical sites within this drainage. Currently, this species is present at $27.3 \%$ of these historical sites. The abundance of plains topminnow was low ( $\leq 5$ individuals) at $72.3 \%$ of the recent collection localities in Nebraska (Table 2). For sites sampled by the present study's protocol, high and moderate abundances of plains topminnow were detected through dip net sampling across the entire site. If no topminnow were detected with dip net sampling, seining and electrofishing only detected low abundance ( $\leq 5$ individuals).

\section{Oklahoma}

Plains topminnow were not found at any of the 18 historical collection sites in Oklahoma (Fig. 4, Table 1), but the species was collected at 2 of the previously unsampled sites (Fig. 5, Table 1). However, the Oklahoma database did not include complete sampling efforts at new sampling locations; thus, the results do not include the number of sites surveyed from which plains topminnow was not collected. Presently, plains topminnow inhabit Spring and Spavinaw Creeks within Cherokee and Delaware counties. Both current sites are reported to have high relative abundance of plains topminnow.

\section{South Dakota}

Plains topminnow were present at $18.8 \%$ of 32 historical collection sites (Fig. 4, Table 1). In addition,
Table 3. Fundulus sciadicus. Recorded detection probabilities $(\%$; mean $\pm \mathrm{SE})$ for 40 intensive sampling sites in Nebraska. Detection probabilities are recorded for 1, 2 and 3 sampling visits, as well as for recorded abundances - high ( $\geq 30$ individuals, $\mathrm{n}=10$ ), moderate (6 to 29 individuals, $\mathrm{n}=10)$ and low/none ( $\leq 5$ individuals, $\mathrm{n}=20)$ - based on the number of plains topminnow collected in the past $10 \mathrm{yr}$

\begin{tabular}{|cccccc|}
\hline \multirow{2}{*}{ Abundance } & \multirow{2}{*}{ Overall } & \multicolumn{4}{c|}{ Abundance } \\
\cline { 3 - 6 } & & High & Moderate & Low/None \\
\hline 1 & $76.4 \pm 4.6$ & $96.7 \pm 2.3$ & $96.7 \pm 2.3$ & $68.4 \pm 10.6$ \\
2 & 94.6 & - & - & - \\
3 & 98.1 & - & - & - \\
\hline
\end{tabular}

the species was collected at 5 previously unsampled sites (Fig. 5, Table 1). Presently, plains topminnow inhabit tributaries to the Cheyenne, Little White, Keya Paha, Vermillion and James Rivers, with no plains topminnow found in the South Dakota portion of the Niobrara River drainage. Twenty of the historical sites were found to be dry. The relative abundance of plains topminnow was low ( $\leq 5$ individuals) at $54.5 \%$ of 11 recent collection localities in South Dakota (Table 2).

\section{Wyoming}

Plains topminnow were present at $70.0 \%$ of 10 historical collection sites in Wyoming (Fig. 4, Table 1). In addition, the species was collected at 78 of 267 previously unsampled sites (Fig. 5, Table 1). Presently, the plains topminnow primarily inhabits tributaries to the Cheyenne River, where they are considered to be an introduced species.

\section{Detection probability}

Detection probabilities for plains topminnow at intensive monitoring sites revealed a $0.76 \pm 0.05$ probability of detection with one visit (Table 3 ). Detection probabilities were highest $(0.97 \pm 0.02)$ with a single sampling visit when the sampling site had moderate (6 to 29 individuals) to abundant ( $\geq 30$ individuals) plains topminnow populations (Table 3). At sites with low relative abundance ( $\leq 5$ individuals), there was a $0.69 \pm 0.11$ probability that the species would be detected (Table 3). During repeated monitoring, an individual plains topminnow was caught at a site that had not detected the species in the past $10 \mathrm{yr}$. For calculation of detection probabilities, sites with 0 and $<5$ individuals detected were combined. We found that with repeated sampling at locations, detection probabilities for plains topminnow increased to 0.95 
and 0.98 for 2 and 3 samplings, respectively (StatTrek 2009) (Table 3).

\section{DISCUSSION}

\section{Historical locations}

Results indicated a $71.7 \%$ reduction in the number of historical locations currently supporting plains topminnow populations. A reduction in known locations identifies a trend of lost continuity in plains topminnow populations throughout their entire range. Adjustments for detection probabilities may slightly diminish the severity of the observed plains topminnow loss. However, if this species was not detected, it likely would exist only in low abundance at a location. It is also important to use caution in comparing the results from recent sampling efforts with those generated over the historical time frame because stream ecosystems and their fish assemblages are dynamic and strongly influenced by precipitation patterns. Despite these limitations, comparisons of recent and historical records are necessary to monitor and document changes in species distribution and abundance.

Three states, Iowa, Kansas and Oklahoma, displayed $100 \%$ reduction in historical locations supporting plains topminnow populations and both Iowa and Kansas consider this species to be extirpated (Harlan et al. 1987, Haslouer et al. 2005). However, locations in Minnesota in the Rock River drainage were just upstream of the Iowa border and it is likely that plains topminnow could be found in this Iowa drainage. Oklahoma has 2 new locations with plains topminnow populations and both of these had high relative abundance of the species ( $>30$ individuals), indicating that suitable conditions exist in this region.

Nebraska holds nearly two-thirds of all of the historical locations for plains topminnow. Sampling efforts revealed a $65.6 \%$ reduction in the number of historical locations currently supporting plains topminnow. Our results were similar to those of Haas (2005), who found a $70.8 \%$ reduction in occurrence among 130 historical plains topminnow locations. Fischer \& Paukert (2008) also found that plains topminnow were absent from $77.4 \%$ of the sites in the northern Sandhills of Nebraska ( $\mathrm{n}=31)$, where it had been historically found. Although the Republican River plains topminnow are thought to be introduced, reductions in populations there suggest that other locations, such as those in Wyoming, with introduced populations may not protect against loss of this species.

\section{Additional sampling efforts}

Along with sampling at historical plains topminnow locations, an additional 1109 locations with apparently suitable habitat were visited. Of the additionally sampled sites, $202(18.2 \%)$ contained plains topminnow (Fig. 3, Table 1). Wyoming, Nebraska and Minnesota had the largest numbers of new locations currently supporting plains topminnow populations (Table 1). Minnesota and Wyoming were the only states to have observed increases in the total number of locations supporting populations of plains topminnow. In addition, Minnesota observed 100\% of historical sites sampled still supported plains topminnow populations, although all locations were in a relatively small area of the state. Although Wyoming exhibited increases in new site occupancy by plains topminnow, revisiting historical locations showed a $30.0 \%$ decline. Overall, the finding that plains topminnow occur in approximately $18 \%$ of the new sites visited shows that the species does not occur in all potentially favorable habitats.

A likely explanation for the expansion in the known range for plains topminnow collections in Minnesota is because of intensive stream monitoring within the Rock River drainage, where 411 new locations were surveyed while sampling for Topeka shiner. Of the sampling efforts, $8.1 \%$ yielded new plains topminnow locations. Also during 2004, the Rock River drainage in southern Minnesota underwent a habitat reclamation project. The reclamation project reduced siltation and decreased stream channelization, which restored backwater habitats, as well as riparian and in-stream vegetation (MDNR unpubl. data).

In Wyoming, an increase in the number of plains topminnow collection locations resulted from the sampling of 267 new locations. Additionally, the unintentional introduction of plains topminnow into the Cheyenne River drainage, thought to be associated with the stocking of warm-water fishes, resulted in a range expansion, with an additional 38 locations supporting populations (Baxter \& Simon 1970).

The decline of plains topminnow appeared to follow a gradient from south to north, with the greatest declines in the southern portion of the range. Nebraska had a $65.6 \%$ reduction in historical sites supporting the species, with the largest reductions in number of sites that support plains topminnow occurring in the southern tributaries of the state (Platte River $80.0 \%$ : Republican River $72.7 \%$ ). The northern portion (Wyoming and Minnesota) of the distribution appeared to be stable or potentially expanding. 


\section{Detection probability}

We used sampling visits to 40 locations in $\mathrm{Ne}$ braska to generate the overall mean detection probability estimate for plains topminnow, which was $0.76 \pm 0.05$ for one visit (Table 3). PRESENCE was also used by CDW, who found a $0.83 \pm 0.09$ probability of detection for plains topminnow with a single pass using their sampling protocol $(\mathrm{H}$. Crockett pers. comm.). They also found that with repeated sampling, the probability of detecting plains topminnow in at least one of 3 sampling passes at a site was 0.99 (CDW unpubl. data).

Statistical programs such as PRESENCE create and use models for estimating the site occupancy and detection probabilities for a target species (MacKenzie et al. 2004). Primarily, PRESENCE has been used for amphibian species with low detection probabilities (Bailey et al. 2004, Smith et al. 2006). Sampling at intensive monitoring locations, coupled with the use of PRESENCE, allows estimation of the detection probabilities of a species. However, repeated sampling at sites across the geographic range of a species may not be practical or possible given time and access constraints.

In Nebraska, locations with low ( $\leq 5$ individuals) relative abundances of plains topminnow had lower $(0.68 \pm 0.11)$ detection probabilities compared with locations with moderate and high relative abundance $(0.97 \pm 0.02)$. It is important to recognize that habitats occupied by plains topminnow in other drainages and other states may differ from those in Nebraska, and the probabilities of detection could thus be lower or higher. Our results indicate that in order to detect trends in plains topminnow populations, particularly in low-abundance locations, every effort should be made to re-sample sites multiple times, as has been suggested for amphibian species (Smith et al. 2006). With more intensive, longer-term sampling at a greater number of sites, PRESENCE can be used to model factors that would be expected to affect occupancy, such as habitat type, co-occurrence of predators or nonnative competitors, and drought (MacKenzie et al. 2004, Smith et al. 2006).

\section{Potential threats}

Plains topminnow were not collected from a large portion of historical sites across their geographic range. These declines were paralleled with the loss of riverine species, including the federally endan- gered Topeka shiner and the Nebraska state endangered northern redbelly dace Phoxinus eos (Ricciardi \& Rasmussen 1999, Fischer \& Paukert 2008, Volcan et al. 2011). No singular cause seems to be responsible across the range of plains topminnow, but observed factors include stream alterations, degradation of habitat, loss of stream connectivity and the introduction and spread of non-native species.

As with other studies, current surveys found that plains topminnow occurred in relatively isolated populations across watersheds (Propst \& Carlson 1986, Pflieger 1997, Rahel \& Thel 2004). These patchy distributions most likely reflect the lack of suitable habitat connections among appropriate habitats. Because backwater areas historically would be frequently created and lost in prairie streams, re-colonization of these depopulated areas was likely an important aspect in the evolutionary history of plains topminnow. However, lowered water tables, drought, and the construction of culverts and dams likely limit re-colonization by plains topminnow (Winston et al. 1991, Dodds et al. 2004). Although this has not specifically been examined for plains topminnow, barriers and loss of stream connectivity has been shown in the decline of other prairie stream fishes, including the Arkansas darter Etheostoma cragini (Labbe \& Fausch 2000).

Another potential threat to plains topminnow populations is the introduction of nonnative fishes. Rahel \& Thel (2004) found that plains topminnow were seldom collected in association with larger piscivorous fishes. Historically, piscivorous sport fish such as largemouth bass Micropterus salmoides and green sunfish Lepomis cyanellus were absent or rare in prairie stream drainages (Rahel \& Thel 2004). However, the construction of stock ponds and irrigation reservoirs has led to the widespread stocking of sport fish across the United States. Predatory fish are capable of escaping impoundments during flood events and persisting in small streams. The impact of sport fish stockings have not been studied for this species, but have the potential to be detrimental to a smallspecies such as plains topminnow. Previously, Schrank et al. (2001) found that the extirpation of the endangered Topeka shiner in Kansas was linked to the abundance of introduced largemouth bass. In addition to the introduction of non-native predatory sport fish, riverine environments have often experienced shifts in species assemblages towards non-native generalist species (Fischer \& Paukert 2008). One such species that has been widely implicated in declines of native species is the western mosquitofish Gambu- 
sia affinis. The western mosquitofish has been implicated in the reduction of plains topminnow populations (Lynch \& Roh 1996, Haas 2005) and has affected species assemblages through predation, competition and harassment, leading to the reduction and elimination of fish species, aquatic invertebrates and amphibian communities around the world (Meffe 1985, Moyle 2002, Mills et al. 2004, Zeiber et al. 2008). Whether the western mosquitofish threatens the plains topminnow is not clear. Goldsworthy \& Bettoli (2006) observed reduced reproductive success in the Barrens topminnow Fundulus julisia, a related species, when mosquitofish were present. Additionally, mixed populations displayed no evidence of Barrens topminnow recruitment (Goldsworthy \& Bettoli 2006). In aquarium studies, Laha \& Mattingly (2006) observed mosquitofish predation on juvenile Barrens topminnow.

Our study sought to update the distribution of plains topminnow across its range and compare it with historical distributions. Although limitations exist and comparison of all historical records to data generated across only 10 yr should be viewed with caution, it is evident that plains topminnow have been eliminated from a large portion of their historical range $(71.6 \%)$. This observation is further supported by additional sampling conducted, which found plains topminnow to be present in only $18.2 \%$ of sites; this is a conservative estimate, as many states did not report all data for sites where plains topminnow were not found during surveys.

The pattern of decline appears to follow a gradient, with the greatest losses of plains topminnow from southern areas. This pattern of loss suggests that competition from mosquitofish, which generally have poor overwinter survival in their northern range (Haas 2005), may be a factor. To better understand the plains topminnow's current status, further research is necessary to determine the species' critical habitat, home range, recolonization abilities and limiting factors affecting its distribution. It is not possible to determine whether the decline in distribution will continue or whether the plains topminnow distribution has stabilized, or whether, in fact, increases in distribution will continue to occur in Minnesota and Wyoming.

Acknowledgements. Funding for this project was provided by the USFWS. All research presented here was conducted under the University of Nebraska IACUC protocols. Special thanks go to Courtney Finney, Josh Cloeter, Kyle Charron, Mike Smith, Jordan Katt, Ryan Thorson, Justin Haas, and Jeremy Pasbrig for their help with data collection and field- work. We also thank the NGPC for providing equipment used in this study, and the state and federal agencies who aided in stream sampling and providing data. Special thanks to the CDW, especially Harry Crockett, Harry Vermillion, and Ryan Fitzpatrick; IDNR, especially John Olson and Daryl Howell; USFWS, especially Vernon Tabor (Kansas) and Greg Wanner (South Dakota); MDNR, especially Konrad Schmidt; St. Olaf College, Dr. Pat Ceas; MDC, Robert Hrabik; MSSU, Dr. Robert Heth; SDGFP, Andy Burgess and Doug Backlund; and WGFD, Beth Bear and Christina Barrineau. Finally, thanks to Dr. Marc Albrecht for assistance in creating the GIS maps for this manuscript.

\section{LITERATURE CITED}

Anderson CP, Erickson JE, Ross J, Underhill JC (1977) Revised distributional records of some Minnesota fishes. J Minn Acad Sci 43:3-6

Austin B (1998) The effects of pollution on fish health. J Appl Microbiol 85:234S-242S

Bailey RM, AO Allum (1962) Fishes of South Dakota. Miscellaneous Publication No. 119. University of Michigan. Museum of Zoology, Ann Arbor, MI

Bailey LL, Simons TR, Polluck KH (2004) Estimating site occupancy and species detection probability parameters for terrestrial salamanders. Ecol Appl 14:692-702

Baxter GT, Simon JR (1970) Fishes of Wyoming. Wyoming Game and Fish Department, Cheyenne, WY

Baxter GT, Stone MD (1995) Fishes of Wyoming. Wyoming Game and Fish Department, Cheyenne, WY

Bazata K (2005) Nebraska stream classification using fish, macroinvertebrates, habitat, and chemistry evaluations from R-EMAP data, 1997-2005. Nebraska Department of Environmental Quality, Lincoln, NB

Bonner TH, Wilde GR (2002) Effects of turbidity of prey consumption by prairie stream fishes. Trans Am Fish Soc 131:1203-1208

Brinkman MA (1994) Observations of the plains topminnow in South Dakota. Prairie Nat 26:307-308

Ceas PA, Larson KA (2009) Topeka shiner monitoring in Minnesota: year six. Final report submitted to the Division of Ecological Resources, Minnesota Department of Natural Resources, Northfield, MN

Crockett HJ (2008) Draft warmwater stream fish monitoring manual. Colorado Division of Wildlife. Fort Collins, CO

Cross FB, JT Collins (1995) Fishes in Kansas. Natural History Museum, The University Press of Kansas, Lawrence, KS

> Crowl TA, Townsend CR, Mcintosh AR (1992) The impact of introduced brown and rainbow trout on endemic fish: the case of Australasia. Rev Fish Biol Fish 2:217-241

Cumming GS (2004) The impact of low-head dams on fish species richness in Wisconsin, USA. Ecol Appl 14: 1495-1506

> Dodds WK, Gido K, Whiles MR, Fritz KM, Matthews WJ (2004) Life on the edge: the ecology of Great Plains prairie streams. Bioscience 54:205-216

Environmental Monitoring and Assessment Program (1991) America's ecological report card: Environmental Monitoring and Assessment Program (EMAP) [video]. Report NR EPA/600/V-92/001, US Environmental Protection Agency, Washington, DC

Everhart WH, Seaman WR (1971) Fishes of Colorado. Colorado Game, Fish, and Parks Division, Denver, CO 
Fischer SA, Combes MD (2003) Resource assessment and monitoring program: standard operation procedures-fish sampling. Missouri Department of Conservation. Kirksville, MO

Fischer JR, Paukert CP (2008) Historical and current environmental influences on an endemic Great Plains fish. Am Midl Nat 159:364-377

Goldsworthy CA, Bettoli PW (2006) Growth, body condition, reproduction and survival of stocked Barrens topminnow, Fundulus julisia (Fundulidae). Am Midl Nat 156: 331-343

Haas JD (2005) Evaluation of the impacts of the introduced western mosquitofish, Gambusia affinis, on endemic plains topminnow, Fundulus sciadicus, in Nebraska. MSc thesis, University of Nebraska, Kearney, NB

Harlan JR, Speaker EB (1956) Iowa fish and fishing. Iowa Conservation Commission, Des Moines, IA

Harlan JR, Speaker EB, Mayhew J (1987) Iowa fish and fishing. Iowa Department of Natural Resources, Des Moines, IA

Haslouer SG, Eberle ME, Edds DR, Gido KB and others (2005) Current status of native fish species in Kansas. Trans Kans Acad Sci 108:32-46

Heth R (2005) Survey of Oklahoma plains topminnow, Fundulus sciadicus. Missouri Southern State University, Joplin, MO

Hubbs CL (1926) Studies of the fishes of the order Cyprinodontes, VI. University of Michigan Museum of Zoology, Miscellaneous Publications No. 16, p 86

Hubbs CL, Ortenburger AI (1929) Further notes on the fishes of Oklahoma with descriptions of new species of Cyprinidae. Publication of the University of Oklahoma. Biological Survey 1:17-43

Johnson RE (1942) The distribution of Nebraska fishes. PhD thesis, University of Michigan, Ann Arbor, MI

Jowett IG, Richardson J, Boubee JAT (2009) Effects of riparian manipulation on stream communities in small streams: two case studies. N Z J Mar Freshw Res 43: 763-774

Labbe TR, Fausch KD (2000) Dynamics of intermittent stream habitat regulate persistence of a threatened fish at multiple scales. Ecol Appl 10:1774-1791

Laha M, Mattingly HT (2006) Ex situ evaluation of impacts of invasive mosquitofish on the imperiled Barrens topminnow. Environ Biol Fishes 78:1-11

Larrabee AP (1926) An ecological study of the fishes of the Lake Okoboji region. Univ Iowa Stud Nat Hist 11:1-35

Lee DS, Gilbert CR, Hocutt CH, Jenkins RE, McAllister DE, Stauffer JR Jr (1980) Atlas of North American freshwater fishes, 1st edn. North Carolina Biological Survey Publication \#1980-12. North Carolina State Museum of Natural History, Raleigh, NC

Lynch JD (1988) Introduction, establishment, and dispersal of western mosquitofish in Nebraska (Actinopterygii: Poecilidae). Prairie Nat 20:203-216

Lynch JD, Roh BR (1996) An ichthyological survey of the forks of the Platte River in western Nebraska. Trans Nebr Acad Sci 23:65-84

MacKenzie DI, Bailey LL, Nichols JD (2004) Investigating species co-occurrence patterns when species are detected imperfectly. J Anim Ecol 73:546-555

Matthews WJ (1988) North American prairie streams as systems for ecological study. J N Am Benthol Soc 7:387-409

McCartney MP (2002) Freshwater ecosystem management: from theory to application. Int J Water 2:1-16
Meek SE (1894) Notes on the fishes of western Iowa and Eastern Nebraska. Bull US Fish Comm 14:133-138

Meffe GK (1985) Predation and species replacement in southwestern fishes: a case study. Southwest Nat 30: 173-187

Mills MD, Rader RB, Belk MC (2004) Complex interactions between endemic and invasive fish: the simultaneous effects of multiple negative interactions. Oecologia 141: 713-721

Moyle PB (2002) Inland fishes of California. University of California Press, Berkley, CA, p 251-269

NatureServe (2011) NatureServe Explorer: an online encyclopedia of life. Version 7.1. NatureServe, Arlington, VA, available at www.natureserve.org/explorer

> Patton TM, Hubert WA (1993) Reservoirs on a Great Plains stream affect downstream habitat and fish assemblages. J Freshwat Ecol 8:279-285

Pflieger WL (1997) The fishes of Missouri. Missouri Department of Conservation, Jefferson City, MO

$>$ Propst DL, Carlson FA (1986) The distribution and status of warmwater fishes in the Platte River drainage, Colorado. Southwest Nat 31:149-167

Quist MC, Huber WA, Rahel FJ (2004) Warmwater stream assessment manual. Wyoming Game and Fish Department, Cheyenne, WY

Rahel FJ (2002) Homogenization of freshwater faunas. Annu Rev Ecol Evol Syst 33:291-315

Rahel FJ, Thel LA (2004) Plains topminnow (Fundulus sciadicus): a technical conservation assessment. USDA Forest Service, Rocky Mountain Region, available at www.fs. fed.us/r2/projects/scp/assessment/plainstopminnow.pdf

Ricciardi A, Rasmussen JB (1999) Extinction rates of North American freshwater fauna. Conserv Biol 13:1220-1222

Richter BD, Braun DP, Mendelson MA, Master LL (1997) Threats to imperiled freshwater fauna. Conserv Biol 11: 1081-1093

Schrank SJ, Guy CS, Whiles MR, Brock BL (2001) Influence of instream and landscape-level factors on the distribution of Topeka shiners Notropis topeka in Kansas streams. Copeia 2001:413-421

Simon JR (1946) Wyoming fishes. Wyoming Game and Fish Department, Cheyenne, WY

Smith LL, Barichivich WJ, Staiger JS, Smith KG, Dodd CK Jr (2006) Detection probabilities and site occupancy estimates for amphibians at Okefenokee National Wildlife Refuge. Am Midl Nat 155:149-161

StatTrek (2009) StatTrek Probability Calculator. Available at http://stattrek.com/Tools/ProbabilityCalculator.aspx

Ulltang O (1998) Explanations and predictions in fisheries science-problems and challenges in a historical and epistemological perspective. Fish Res 37:297-310

> Volcan MV, Gonçalves AC, Lanés LEK (2011) Distribution, habitat and conservation status of two threatened annual fishes (Rivulidae) from southern Brazil. Endang Species Res 13:79-85

Wang L, Brenden T, Seelback P, Cooper A, Allan D, Clark R Jr, Wiley M (2008) Landscape based identification of human disturbance gradients and reference conditions for Michigan streams. Environ Monit Assess 141:1-17

Weitzel DL (2002) Conservation and status assessments for the finescale dace (Phoxinus neogaeus), pearl dace (Margariscus margarita), and plains topminnow (Fundulus sciadicus): Rare endemic fish species of the Niobrara and Platte Basins, Wyoming. Wyoming Fish and Game Department, Cheyenne, WY 
Williams J, Johnson E, Hendrickson DA, Contreras-Balsderas S and others (2008) Fishes of North America, endangered, threatened, of special concern. Fisheries 12:2-20

Winston MR, Taylor CM, Pigg J (1991) Upstream extirpation of four minnow species due to damming of a prairie stream. Trans Am Fish Soc 120:98-105

Editorial responsibility: Craig Paukert, Columbia, Missouri, USA
Zabel RW, Williams JG (2002) Selective mortality in Chinook salmon: what is the role of human disturbance? Ecol Appl 12:173-183

Zeiber RA, Sutton TM, Fisher BE (2008) Western mosquitofish predation on endemic amphibian eggs and larvae. J Freshw Ecol 23:663-672

Submitted: May 26, 2011; Accepted: November 5, 2011 Proofs received from author(s): February 13, 2012 